the undeformed $S_{2}$ developed in the host rock during the later growth of the $F_{2}$ system by planar-slip.

Discordant veining was emplaced at a later stage in the $F_{2}$ movement along the already formed $S_{2}$ and therefore transects bedding and $S_{1}$. Small veins of this type have the form of thin, planar lenses with a lenticular crosssection. On a larger scale the quartz adopts the form of thick pods or augen which thin out rapidly towards their margins. A favourite site for these larger bodies, up to several feet thick, is along the axial planes of mesoscopic $F_{2}$ flexures.

Much irregular veining of $F_{2}$ age also traverses the Manx Slate Series with no regard for the pre-existing $S$-planes. The injection of such veining evidently took place throughout the $F_{2}$ movement. The earlier influxes are affected by $F_{2}$ crumpling and cut by $S_{2}$ while the later material is only disrupted by the cleavage. A proportion of the irregular veining, injected at the close of the second movement, anastamoses discordantly through all the $F_{2}$ minor structures.

The bulk of the quartz-veining in the Manx Slate Series is of $F_{2}$ age. Only small amounts were occasionally injected during the last $\left(F_{3}\right)$ phase of folding. Such veining is restricted to sporadic localities where $F_{3}$ minor crumpling is more strongly developed than usual. In the south-western tip of the Island it has been observed along minor $F_{3}$ slides and may occupy tension gashes opened in competent quartzite by $F_{3}$ bedding-slip.

Department of Geology,

A. Simpson

Birkbeck College,

University of London.

${ }^{1}$ Simpson, A., Quart, J. Geol. Soc., 119, 368 (1963).

2 Simpson, A., Geol. Mag. (in the press).

\section{Source of the Glencoe Ignimbrites}

IGNIMBRITES $^{1,2}$ are a characteristic component of the typically post-orogenic basalt-andesite-rhyolite volcanic association. These pyroclastic deposits are now generally accepted $^{2}$ as having been produced by eruptions of nuées ardentes in which solid particles, both rock and crystal fragments, glass shards and pumice fragments are suspended by turbulent flow in gas, probably derived in part from the glass shard and pumice material itself ${ }^{3}$. Such a fluidized system ${ }^{4}$ forms the basal avalanche of a nuée ardente. While associated with several types of volcanic structure, most of those ignimbrite deposits with a volume greater than $10 \mathrm{~km}^{3}$, and the source of which is known, have been related either to calderas or, for the larger volume $\left(>1,000 \mathrm{~km}^{3}\right)$ deposits, to volcano-tectonic depressions ${ }^{3}$. No intrusive igneous body has yet been recognized which, on clear-cut evidence, served as a feeder for extensive ignimbrite flows ${ }^{3}$.

At Glencoe, Scotland, an approximately cylindrical mass of metamorphic rocks overlain by a thick pile of Lower Devonian volcanics subsided in two stages within ring-faults. During the cauldron subsidence the early and main Glencoe Fault Intrusions were emplaced as discontinuous ring-complexes up the ring faults ${ }^{5}$. Within the lava sequence, consisting largely of andesites and rhyolites, recent work by me has lead to the recognition of two thick ignimbrite sheets within Groups 2 and 5 (ref. 5). Both ignimbrites are rhyodacites, the lower being a lithic tuff rich in fragments of the underlying rhyolites and andesites, the upper a crystal tuff containing abundant felspar crystals. At the present level of erosion the lower horizon thickens towards the centre of the cauldron suggesting a caldera form at the time of eruption. The presence of Group 2 (ref. 5) rhyolite lavas and of Group 3 (ref. 5) volcanic conglomerates towards the margins confirms this view. The vulcanicity, rather than being "the quietly welling, effusive type", as originally thought ${ }^{5}$, was explosive in nature.
Calderas are often the surface expression of the emplacement of ring dykes and complexes in depth by cauldron subsidenc $\theta^{6,7}$, accepted by most workers ${ }^{7}$ as the product of magmatic stoping. Reynolds ${ }^{4,6}$, however, has suggested that such complexes may be emplaced as fluidized systems of gas, solid fragments and, if the temperature is high enough, liquid droplets. On reaching the surface, this forms ignimbrite. Part of Reynolds's evidence $\theta^{6}$ for fluidization comes from the published deseription ${ }^{5}$ of the type locality of the main Glencoe Fault Intrusion at Stob Mhic Mhartuim, recently studied in detail by me. Here the porphyritoid facies of the fault intrusion is in contact with the downfaulted metamorphic rocks within the cauldron subsidence. The contact is marked by a narrow zone of "flinty crush-rock", originally interpreted as a product of frictional heat generated on the fault-surface during subsidence ${ }^{5}$. As Reynolds ${ }^{6}$ suggests, in actuality it is an extremely fine-grained tuffisite formed by gas attrition of the conduit walls during the emplacement of the fault intrusion as a fluidized system. A similar contact is found against the country rocks outside the cauldron subsidence.

On this evidence it is suggested that the two ignimbrite horizons within the volcanic pile were derived respectively from the early and main Glencoe Fault intrusions during two periods of cauldron subsidence. The porphyritoid facies of the fault intrusions contains phenoerysts of plagioclase varying in composition from labradorite to oligoclase, hornblende, biotite and occasional pyroxene in a fine-grained felspathic matrix ${ }^{5}$ The ignimbrites show a more uniform composition. The crystal fragments present are predominantly oligoclase-andesine. Some quartz, not obviously of xenocrystal origin, is found in the upper horizon.

Ferromagnesian minerals, apart from occasional biotite flakes and rare pseudomorphs after hornblende, are generally absent. The ignimbrites thus appear to have been derived from the more acid varieties of the fault intrusion porphyrites, the hornblende and much of the biotite having been destroyed during their emplacement. Hornblendes and some biotites in the porphyrites are often rimmed by corrosion borders of magnetite dust and alteration products, formed by oxidation under nearsurface conditions ${ }^{8}$. On eruption this process would be accentuated, producing the abundant magnetite dust now found in the ground-mass of the ignimbrites.

It is generally accepted that ignimbrites form by the explosive vesiculation of a glassy magma with the subsequent transport of the glass shards thus formed in a fluidized system, the pumice fragments representing the initial stages in this process ${ }^{2}$. Glass shard and pumice textures are not seen in the groundmass of the fault intrusion porphyrites but may have been destroyed by recrystallization. As the porphyrites are 'frozen' fluidized systems, pumice fragments may have been 'flushed' from the system during the earlier stage of flow. However, the lack of glass shard textures, which are generally retained despite recrystallization, suggests that liquid droplets, rather than glass shards as such, were originally present. On reaching the surface these would vesiculate by exsolution of gas to give glass shards. It may be that, towards the surface, the liquid droplets coalesce on the conduit walls to form a glassy layer afterwards disrupted to form the angular pumice fragments characteristic of ignimbrites ${ }^{2}$.

Jane Herdman Laboratories of Geology,

JoHN L. ROBFRTS University of Liverpool.

Marshall, P., Trans. Roy. Soc., N.Z., 64, 323 (1935).

2 Rast, N., Liverpool and Manchester Geol. J., 3, 97 (1962).

${ }^{3}$ Smith, R. L., Geol. Soc. Amer. Bull., 71, 795 (1960).

${ }^{4}$ Reynolds, D. L., Amer. J. Sci., 252, 577 (1954).

${ }^{5}$ Clough, C. T., Maufe, H. B., and Bailey, E. B., Quart. J. Geol. Soc. Lond., 65, 611 (1909).

' Reynolds, D. L., Nederl. Geol.-Mijnb. Gen., Verh., Geol. Ser., 16, 355 (1956).

Buddington, A. F., Geol. Soc. Amer. Bull., 70, 671 (1959).

${ }^{8}$ Turner, F. J., and Verhoogan, J., Ioneous and Metamorphic Petrology (McGraw-Hill, Toronto, 195i). 